\title{
The Porcine Sperm Motility Inhibitor Is Identical to $\beta$-Microseminoprotein and Is a Competitive Inhibitor of $\mathrm{Na}^{+}, \mathrm{K}^{+}$-ATPase
}

\author{
Chih-Fang Chao, * Shean-Tai Chiou, $\dagger$ Hellen Jeng, $\ddagger$ and Wen-Chang Chang $*, \uparrow, 1$ \\ *Institute of Biochemical Sciences, National Taiwan University, Taipei, Taiwan, R.O.C.; †Institute of Biological \\ Chemistry, Academia Sinica, Taipei, Taiwan, R.O.C.; and $\ddagger$ Department of Anatomy, Taipei Medical College,
}

Taipei, Taiwan, R.O.C.

Received December 11, 1995

\begin{abstract}
We have isolated a small porcine seminal protein called SMI-1. Our results from peptide sequence, amino acid composition and mass spectral analyses reveal that SMI- 1 is identical to porcine $\beta$-microseminoprotein, a protein with unknown function. We also report here that this protein inhibits competitively the activity of $\mathrm{Na}^{+}, \mathrm{K}^{+}-$ ATPase purified from porcine cerebral cortex in a dose-dependent manner. The inhibitory effect could be reversed by the addition of ATP. The half-maximal inhibition was achieved at an inhibitor concentration of 90 MM. () 1996 Academic Press, Inc.
\end{abstract}

Seminal plasma is a noncellular component of semen. It provides the environment to maintain the viability and quality of the spermatozoa to ensure the success of fertilization. The lowmolecular-weight constituents of seminal plasma include a wide variety of compounds such as inorganic ions, organic acids, sugars, lipids, steroid, amino acids, polyamines, and nitrogenous bases. From the high-molecular-weight constituents, on the other hand, only proteins have so far been identified (1).

We have previously described the identification of a reversible sperm motility inhibitor from porcine seminal plasma protein which was named SMI-1. The protein shows an apparent molecular weight of $15 \mathrm{kDa}$ as determined by SDS-PAGE (2). It can be detected in the prostate gland and bind to the midpiece and posterior portion of porcine spermatozoa (Jeng et al., submitted, 1995).

$\beta$-Microseminoprotein is a major non-glycosylated protein which was first identified as a 94amino-acid seminal plasma protein secreted by the human prostate (3). The porcine homolog, containing 91 amino-acid residues and 5 disulfide linkages, was purified from seminal plasma and sequenced (6) (Fig. 1, upper line). It was also found in many other biological fluids such as tracheal secretion, gastric juice, and uterine cervical secretions (4). This protein has been characterized and cloned in human and ape $(3,5)$, but its function is still unknown. However, it is believed that the protein may have some function related to mucus secretion (4).

Most mammalian cells have $\mathrm{Na}^{+}, \mathrm{K}^{+}$-ATPases in their membrane, which pump $\mathrm{Na}^{+}$out of and $\mathrm{K}^{+}$into the cell (7). Fractionation of porcine spermatozoa also indicates the presence of $\mathrm{Na}^{+}, \mathrm{K}^{+}$ATPase in the membrane portion (8). Further characterization shows that the distribution of $\mathrm{Na}^{+}, \mathrm{K}^{+}$-ATPase in the spermatozoa is restricted to the flagella membrane located at the middle and posterior part of the spermatozoa $(9,10)$. The coincidence between the distribution site of $\mathrm{Na}^{+}, \mathrm{K}^{+}$ATPase on spermatozoa and the binding of SMI-1 on the sperm surface implicates that SMI-1 may bind and react with $\mathrm{Na}^{+}, \mathrm{K}^{+}$-ATPase.

In this report we will describe the experimental results which reveal the identity between SMI-1 and $\beta$-microseminoprotein as well as the inhibitory effect of SMI- 1 on $\mathrm{Na}^{+}, \mathrm{K}^{+}$-ATPase.

\footnotetext{
${ }^{1}$ To whom correspondence should be addressed.
} 


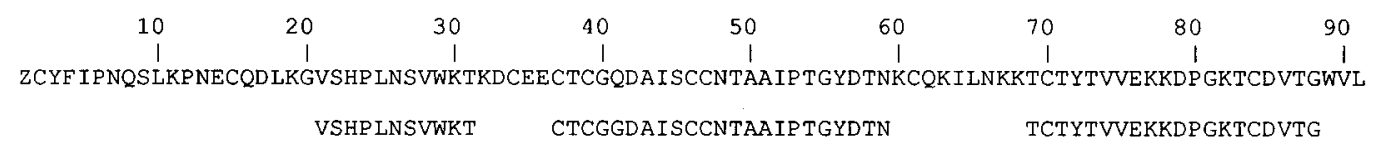

FIG. 1. Comparison between partial peptide sequence of porcine SMI-1 (lower line) and the primary structure of porcine $\beta$-microseminoprotein (upper line). $\mathrm{Z}$ indicates pyroglutamic acid.

\section{MATERIALS AND METHODS}

\section{Preparation of SMI-1}

SMI-1 was prepared by reversed-phase high-performance liquid chromatography (HPLC) of dialyzed porcine seminal plasma as described (2).

\section{Amino Acid Analysis}

SMI-1 was reduced with dithiothreitol and carboxymethylated with iodoacetic acid (11), hydrolyzed with $6 \mathrm{~N} \mathrm{HCl}$ and subjected to amino-acid analysis by an automatic amino-acid analyzer (Beckman model 6300).

\section{Peptide Sequence Analysis}

SMI-1 was reduced and carboxymethylated with iodoacetic acid prior to partial digestion by either trypsin (Pierce) or V8 protease (Boehringer Mannheim) to generate the peptide fragments (12). The fragments were then separated by reversedphase HPLC using an Aquapore RP-300 column $(7 \mu \mathrm{m}, 220 \times 4.6 \mathrm{~mm}$, Applied Biosystems, Inc. USA.). The peptide sequences were then determined in a gas-phase sequencer (Applied Biosystems).

\section{Mass Spectrometry}

SMI-1 was dissolved in $50 \%$ acetonitrile containing $0.1 \%$ acetic acid to make a final concentration of $10 \mu \mathrm{M}$ and analyzed in an API 100 mass spectrometer (PE SCIEX) at an infusion rate of $5 \mu \mathrm{l} / \mathrm{min}$. The spectra were analyzed by a software (BioToolBox) from the manufacturer.

\section{Enzyme and Chemicals}

Adenosine $5^{\prime}$-triphosphatase $\left(\mathrm{Na}^{+}, \mathrm{K}^{+}\right.$-ATPase, from porcine cerebral cortex $)$and ouabain were purchased from Sigma Chemical Co., USA. ATP was purchased from Boehringer Mannheim, Germany.

TABLE 1

Amino Acid Composition of SMI-1 and $\beta$-Microseminoprotein

\begin{tabular}{lcc}
\hline Amino acid & $\begin{array}{c}\text { According to sequence of } \beta- \\
\text { microseminoprotein }(\mathrm{mol} / \mathrm{mol})\end{array}$ & $\begin{array}{c}\text { Carboxymethylated SMI-1 } \\
(\mathrm{mol} / \mathrm{mol})\end{array}$ \\
\hline CM-Cysteine & 10 & 10.3 \\
Aspartic acid & 12 & 12.8 \\
Threonine & 10 & 8 \\
Serine & 4 & 3.1 \\
Glutamic acid & 9 & 9.3 \\
Proline & 5 & 5.1 \\
Glycine & 5 & 7.6 \\
Alanine & 3 & 3.7 \\
Valine & 6 & 6.1 \\
Methionine & 0 & 0 \\
Isoleucine & 4 & 4.2 \\
Leucine & 5 & 5.6 \\
Tyrosine & 3 & 2.9 \\
Phenylalanine & 1 & 1.1 \\
Histidine & 1 & 1.2 \\
Lysine & 11 & 10.7 \\
Arginine & 0 & 0 \\
Tryptophan & 2 & not determined. \\
\hline
\end{tabular}


$\mathrm{Na}^{+}, \mathrm{K}^{+}$-ATPase Activity Assay

The enzyme preparation was incubated in a solution containing $60 \mathrm{mM} \mathrm{Na}_{2} \mathrm{SO}_{4}, 10 \mathrm{mM} \mathrm{K}_{2} \mathrm{SO}_{4}, 5 \mathrm{mM} \mathrm{MgSO}, 0.1 \mathrm{mM}$ EDTA, and $92 \mathrm{mM}$ Tris- $\mathrm{HCl}, \mathrm{pH} 7.4$ at $37^{\circ} \mathrm{C}$. The enzymes were preincubated in the absence of ATP for 6 min, and then the reactions were started by addition of ATP. The amount of inorganic phosphate liberated during 6 min. was then determined by a calorimetric method as described (14). Activity of $\mathrm{Na}^{+}, \mathrm{K}^{+}$-ATPase was calculated from $\mathrm{P}_{\mathrm{i}}$ liberated in the reaction.

\section{RESULTS}

\section{SMI-1 Is Identical to $\beta$-Microseminoprotein}

Since the N-terminus of SMI-1 is blocked, the amino acid sequences from some peptide fragments of protease-digested SMI-1 were determined. To our surprise, we found that all sequenced

A.

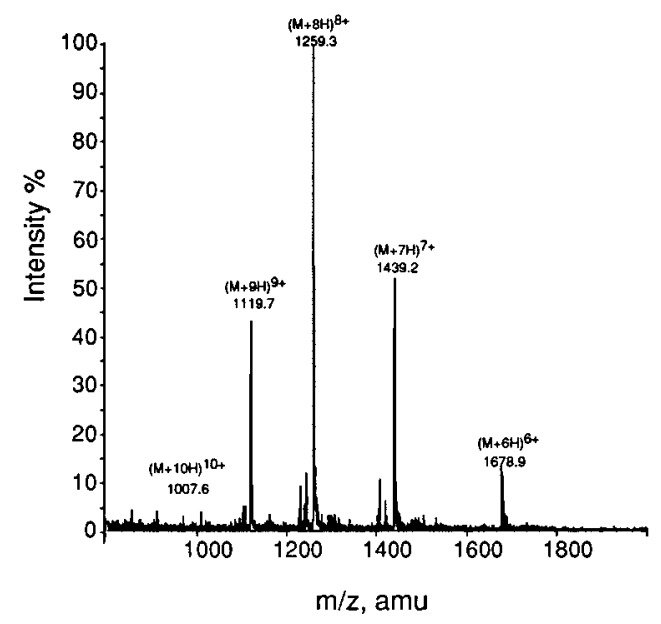

B.

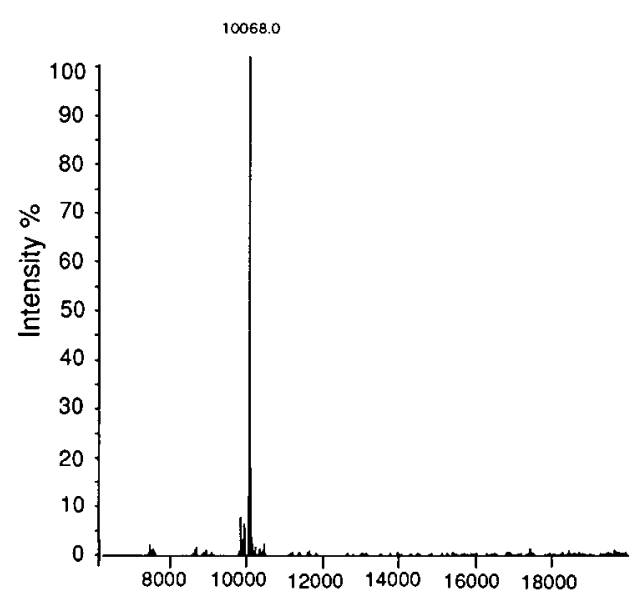

Mass, amu

FIG. 2. Electrospray mass spectrum of the SMI-1. A: original spectrum. B: computer deconvolution of the peaks in A. 


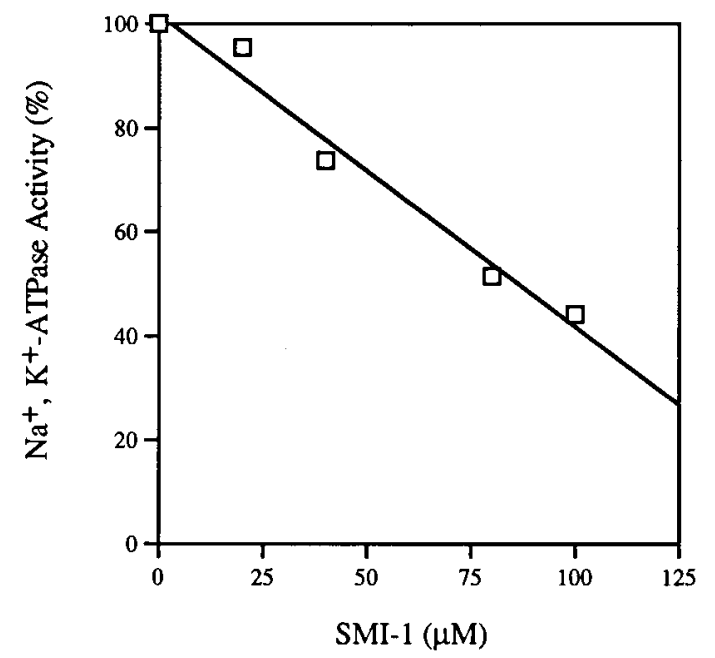

FIG. 3. Inhibitory effects of SMI- 1 on the activity of $\mathrm{Na}^{+}, \mathrm{K}^{+}$-ATPase.

peptides have the same sequences with porcine $\beta$-microseminoprotein (6) as shown in Fig. 1. The comparison of amino acid composition between SMI- 1 and $\beta$-microseminoprotein also indicates that the two proteins are the same or, at least, very similar (Table 1). In addition, the molecular mass of SMI-1 is $10068.0 \pm 1 \mathrm{Da}$ as determined by electrospray mass spectrometry (Fig. 2). This value is practically identical to the reported molecular mass of $\beta$-microseminoprotein determined by the same method $(10069.3 \pm 1 \mathrm{Da})$, or the theoretical value derived from its protein sequence (10068.4 Da) (6). Moreover, the $\mathrm{m} / \mathrm{z}$ values and the general profile for the multiply charged species as shown in Fig. 2 are indistinguishable from those of $\beta$-microseminoprotein (6). Based on the data mentioned above, we conclude that SMI-1 is $\beta$-microseminoprotein.

\section{SMI-1 Is a Competitive Inhibitor of $\mathrm{Na}^{+}, \mathrm{K}^{+}$-ATPase}

The inhibitory effect of SMI- 1 on $\mathrm{Na}^{+}, \mathrm{K}^{+}$was examined using the enzyme purified from porcine cerebral cortex. Fig. 3 shows that SMI- 1 inhibits the $\mathrm{Na}^{+}, \mathrm{K}^{+}$-ATPase activities in a concentrationdependent manner.

The inhibitory effects of SMI-1 and ouabain on the ATPase were compared and shown in Fig. 4. The inhibition of SMI- 1 was competitive with ATP. The potency of SMI-1 $\left(\mathrm{K}_{\mathrm{i}}=90 \mu \mathrm{M}\right)$ was about $1 / 50$ of that of ouabain $\left(\mathrm{K}_{\mathrm{i}}=1.7 \mu \mathrm{M}\right)$.

\section{DISCUSSION}

$\mathrm{Na}^{+}, \mathrm{K}^{+}$-ATPase is responsible for maintaining $\mathrm{Na}^{+} / \mathrm{K}^{+}$gradients in animal cells. It plays a physiological role in regulating water and electrolyte balance (15). $\mathrm{Mg}^{2+}$-dependent ATPase, which is known as dynein, is mainly located in the tail and responsible for the motility of spermatozoa (13). The inhibitory effect of SMI-1 on sperm motility as previously reported (2) may result from the osmotic shock of the sperm due to the inhibition of $\mathrm{Na}^{+}, \mathrm{K}^{+}$-ATPase by SMI-1. It is also possible that SMI-1 may suppress the sperm motility by inhibiting the function of dynein. Further study is required to support this hypothesis.

Some biological peptides with inhibitory activity on $\mathrm{Na}^{+}, \mathrm{K}^{+}$-ATPase have been identified from porcine intestine as SPAIs. This family of peptides contains three members: SPAI-1, -2 , and -3 . SPAI-1 is composed of 49 amino-acid residues, whereas SPAI-2 and SPAI-3 are composed of 61 amino-acid residues (16). These peptides contain 4 disulfide linkages (17). The SPAIs share some 
A.

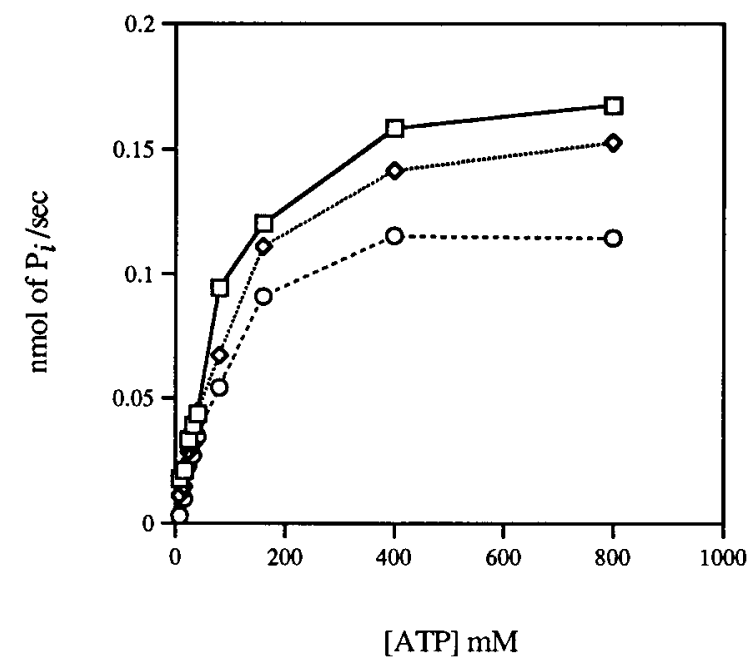

B.

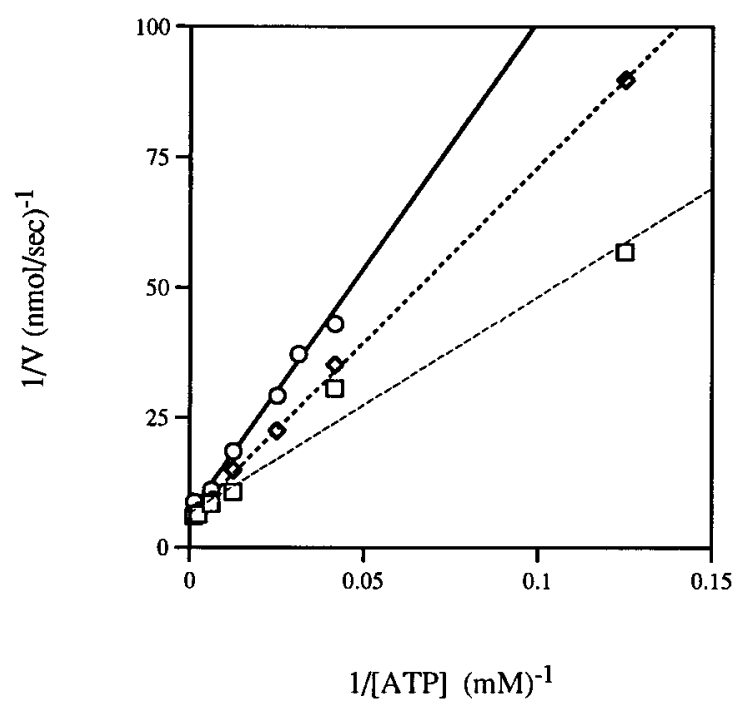

FIG. 4. Kinetics of inhibition on $\mathrm{Na}^{+}, \mathrm{K}^{+}$-ATPase activity by SMI-1. A. Reaction rate of the $\mathrm{Na}^{+}, \mathrm{K}^{+}-\mathrm{ATPase}$ as a function of ATP concentration in the presence of SMI-1 $\diamond$, ouabain $\bigcirc$, or in the absence of inhibitor $\square$. The velocity is expressed as nmoles of inorganic phosphate generated per second. B. Double reciprocal plot of $\mathrm{Na}^{+}, \mathrm{K}^{+}-\mathrm{ATPase}$ activity against ATP in the presence of SMI-1 $\diamond$, ouabain $\bigcirc$, or in the absence of inhibitor $\square$.

similar properties with $\beta$-microseminoprotein. First, both of them are small peptides with extensive disulfide linkages. Second, they have $\mathrm{Na}^{+}, \mathrm{K}^{+}$-ATPase inhibitory effects of comparable potency (16).

The association of $\beta$-microseminoprotein and mucus (4) suggests that the protein may play a role in mucus formation. Although the mechanism of mucous secretion is not well understood, the involvement of $\mathrm{Na}^{+}, \mathrm{K}^{+}$-ATPase in the secretion can not be ruled out since ATP is known to increase the secretions in human tracheal gland cells (18). Furthermore, the potassium channel blocker suppresses the secretion of mucin (19). It is possible that $\beta$-microseminoprotein may play 
some role in the regulation of the secretion of mucus by inhibiting the activity of $\mathrm{Na}^{+}, \mathrm{K}^{+}$-ATPase, which, of course, needs to be investigated further.

\section{ACKNOWLEDGMENT}

This work is supported partially by a grant NSC-85-2311-B-001-052 from the National Science Council of Republic of China.

\section{REFERENCES}

1. Shivaji, S., Scheit, K.-H., and Bhargava, P. M. (1990) Proteins of Seminal Plasma, pp. 1-28, John Wiley \& Sons, New York.

2. Jeng, H., Liu, K.-M., and Chang, W.-C. (1993) Biochem. Biophys. Res. Commun. 191, 435-440.

3. Mbikay, M., Nolet, S., Fournier, S., Benjannet, S., Chapdelaine, P., Paradis, G., Dubé, J. Y., Tremblay, R., Lazure, C., Seidah, N. G., and Chrétien, M. (1987) DNA 6, 23-29.

4. Weiber, H., Andersson, C., Murne, A., Rannevik, G., Lindstrom, C., Lilja, H., and Fernlund, P. (1990) Amer. J. Pathol. 137, 593-603.

5. Nolet, S., Mbikay, M., and Chrétien, M. (1991) Biochim. Biophys. Acta 1089, 247-249.

6. Fernlund, P., Granberg, L., and Roepstorff, P. (1994) Arch. Biochem. Biophys. 309, 70-76.

7. Skou, J. C. (1988) Meth. Enzymol. 156, 1-25.

8. Uesugi, S., and Yamazoe, S. (1966) Nature 209, 403.

9. Ashraf, M., Peterson, R. N., and Russell, L. D. (1982) Biochem. Biophys. Res. Commun. 107, 1273-1278.

10. Eddy, E. M., and O'Brien, D. A. (1992) The Physiology of Reproduction, pp. 29-77. Raven Press, New York.

11. Hirs, C.H. W. (1967) Meth. Enzymol. 11, 199-208.

12. Flannery, A. V., Beynon, R. J., and Bond, J. S. (1989) Proteolytic Enzymes: A Practical Approach, pp. 145-162, IRL Press, Oxford.

13. Holzbaur, E.L. F., and Vallee, R. B. (1994) Annu. Rev. Cell Biol. 10, 339-372.

14. Chow, S. Y., Kemp, J. W., and Woodbury, D. M. (1982) J. Endocrinol. 92, 371-379.

15. Bonting, S. L. (1970) Membranes and Ion Transport, pp. 257-363, Wiley-Interscience, London.

16. Araki, K., Kuroki, J., Ito, O., Kuwada, M., and Tachibana, S. (1989) Biochem. Biophys. Res. Coummun. 164, $496-502$.

17. Araki, K., Kuwada, M., Ito, O., Kuroki, J., and Tachibana, S. (1990) Biochem. Biophys. Res. Commun. 172, $42-46$.

18. Merten, M. D., Breittmayer, J. P., Figarella, C., and Frelin, C. (1993) Amer. J. Physiol. 265, L479-487.

19. Marcon, M. A., McCool, D., Forstner, J., and Forstner, G. (1990) Biochim. Biophys. Acta 1052, 17-23. 